\title{
Magmatism and mantle composition at the slow-spreading Mohns Ridge
}

\author{
A. BJERGA ${ }^{1 *}$, H. H. STUBSEID ${ }^{1}$ AND R. B. PEDERSEN ${ }^{1}$
}

${ }^{1}$ Department of Earth Science and K.G. Jebsen Center for Deep Sea Research, University of Bergen, Allégaten 41, N-5007 Bergen, Norway (*correspondence:

anders.bjerga@gmail.com, håvard.stubseid.uib.no, rolf.pedersen@uib.no)

Despite the fact that most of the volcanic and magmatic activity on Earth occur along the mid-ocean ridges, studies targeting the lower oceanic crust and the underlying mantle have been largely conducted in on-land analogues. Midocean ridges spreading at slow rates are characterized by lower magma budgets and spreading may be dominated by movement along faults leading to uplift of deeper parts of the oceanic lithosphere in oceanic core complexes.

The Schulz Massif $\left(73.4^{\circ} \mathrm{N}\right)$ is a major feature in the bend between the Mohns and Knipovich Ridge. It is a domeshaped seamount $35 \times 10 \mathrm{~km}$ in extent, stretching from $\sim 2600 \mathrm{~m}$ depth to $\sim 630 \mathrm{~m}$ depth. The Schulz Massif is located $\sim 25 \mathrm{~km}$ away from the present day axial spreading-ridge and is associated with positive magnetic and gravimetric anomalies. A variety of gabbroic rocks, peridotites and diabase were collected from dredges and in-situ ROV sampling of outcrops along the uplifted fault surface.

Peridotites are serpentinized harzburgites with only one sample containing relics of cpx. They have Cr-spinel Cr\# $(\mathrm{Cr} /(\mathrm{Cr}+\mathrm{Al}))$ between $0.35-0.41$ and parallell HREE lower than primitive mantle suggesting moderate to high degrees of partial melting. Nonetheless, they have high contents of both $\mathrm{Al}_{2} \mathrm{O}_{3}$ (1.6-2.6 wt.\%) and $\mathrm{Na}_{2} \mathrm{O}(0.36-0.40$ wt.\%) suggesting either local scale mantel heterogenities or that the original mantle composition was initally enriched in $\mathrm{Al}$ and $\mathrm{Na}$. All recovered mantle rocks lack the LREE-depletion, commonly observed in melt-depleted abyssal peridotites, indicating a post melt-extraction enrichment.

The gabbroic rocks range from primitive plag $+\mathrm{px}$ cumulates to evolved microgabbro and show textures and compositions similar to those observed from the plutonic sections of ophiolite complexes. Olivine-gabbros $(\mathrm{Mg} \#=84$ 85) represent olivine-phyric intrusions into the oceanic lithosphere and indicate deep accumulation of olivine within the oceanic litosphere. Based on the geochemistry and crosscutting relationships, we suggest that the oceanic lithosphere, represented by the Schulz Massif, formed through three generations of magmatism. These results provide new insights into the mechanisms of crustal accretion at slow spreading rates and the structure and composition of the crust at $73.4^{\circ} \mathrm{N}$ 